\title{
ASYLUM PROCEEDINGS IN THE CZECH REPUBLIC DURING THE MIGRATION CRISIS
}

\section{Petr Černý*}

Faculty of Social and Economy Studies, University Jan Evangelista Purkyně, Czech Republic

Judge at Regional court in Ústínad Labem, Czech Republic, E-mail: pcerny@ksoud.unl.justice.cz.

(Received: April 2020; Accepted: May 2020; Published: June 2020)

Abstract: The article deals with the fundamental problems that emerged on the territory of the Czech Republic during the implementation of the asylum procedure throughout the migration crisis in the years 2015 to 2019. Problematic issues related primarily to the detention of migrant asylum seekers were identified by studying the key decisions of national and international courts. The first problematic point was the amendment to the Asylum Act, which required the courts to discontinue proceedings on the review of detention orders after the foreign national was released from detention. Due to the conflict with EU law and the impossibility to claim damages for unlawful detention, this amendment was finally annulled by the Constitutional Court. The second problem was that the factual conditions for asylum seekers in the EU Member State where the asylum seeker was to be transferred for the purpose of processing his/her asylum application, were not examined. In this regard, the situation had since been rectified and the administrative authorities and courts of the Czech Republic already take this aspect into account when deciding whether an asylum seeker detained on the territory of the Czech Republic is to be transferred to the country where he/she applied for asylum. The most serious problem is so far incomplete transposition of the Procedures Directive, in particular Article 46 of the Procedures Directive, which requires from the court to review the decisions on asylum in full jurisdiction and could possibly grant asylum itself. However, this requirement does not correspond to the concept and system of administrative courts in the Czech Republic and would require a significant and costly change. The last issue identified was the poor implementation of the Dublin III Regulation, involving not setting serious risk of absconding of an asylum seeker as a precondition for his/her detention directly in the law.

Keywords: Asylum proceedings, detention of a foreign citizen, law of EU, asylum law, Czech Republic.

${ }^{*}$ Corresponding author: Petr Černý. E-mail: pcerny@ksoud.unl.justice.cz.

Copyright (C) 2020 The Author(s). Published by VGWU Press

This is an Open Access article distributed under the terms of the Creative Commons BY 4.0 license (Creative Commons - Attribution 4.0 International - CC BY 4.0) which permits unrestricted use, distribution, and reproduction in any medium, provided the original author and source are credited. 
Černý, P., (2020)

"Vasile Goldiş" Western University of Arad

Asylum proceedings in the Czech Republic during the migration crisis

\section{Introduction}

Since 2015 the migration crisis, also known as the refugee crisis, has brought many new challenges for asylum law. The burden of a large number of asylum seekers has tested the functioning of the asylum system of the EU Member States, both in fact and in law. In the following article, attention is paid to the problematic aspects of the functioning of the asylum procedure, which have emerged in recent years in the Czech Republic as one of the EU Member States.

The oldest international regulation on asylum granting in the EU is the Convention relating to the Status of Refugees of 28 July 1951, as amended by the Protocol of 31 July 1967 (the Geneva Convention) [1]. It defines mainly substantive law, i. a. who has refugee status, basic principles of treatment of persons in this position, it regulates the prohibition of discrimination, right of access to the courts or the principle of non-refoulment [2].

Asylum law is further regulated in European Union law, by both directives and regulations that form the so-called framework of the Common European Asylum System (CEAS). The CEAS focuses on qualification directives [3], procedures directives [4] and reception directives [5]. The key CEAS regulation is the Dublin III Regulation [6]. The CEAS regulations and directives dealing with fundamental issues related to the determination of the state responsible for the examination of an asylum application, as well as to whom asylum can be granted and by what procedure. The basic principle of the CEAS is to include the lowest level of standards (minimum standards) in the asylum procedure of the Member States, which must be respected. At the same time, the purpose of CEAS is to provide a higher level of protection to asylum seekers than is guaranteed in the Geneva Convention [7]. A number of CEAS legislation allows the Member States to adopt their own legislation. However, this situation means that in addition to international treaties and European Union regulations, asylum law in the individual Member States is also regulated by national laws. As a result of this situation, there was no real harmonization of legal standards and in some cases no maintenance of the standards resulting from international law [8]. Furthermore, asylum law is complemented by the case-law of national courts and the case-law of the Court of Justice of the European Union, extending asylum law to the European Union by its case law. This must inevitably lead to contradictions between the various components of the asylum legal system. These discrepancies arose especially during the period of the so-called refugee crisis when states tried to respond to the obvious weaknesses of the CEAS within their possibilities. From recent national regulation cases, Italy is introducing new highly questionable legislative measures in an effort to cope with the inflow of migrants. These measures are on one hand motivated by legitimate reasons and on the other, they reduce the existing standard of asylum seekers' rights [9].

\section{Methodology and subject of research}

By analyzing legislation regulating asylum proceedings, judgments of the Court of Justice of the European Union, and courts of the Czech Republic essential issues of concern where conflict of law of European Union and Czech national law in asylum procedures occurs are identified. Description of issues of concern and their solution in the Czech Republic can inspire other countries while solving problems related to their own asylum procedure. This can be considered a way how to avoid mistakes previously made by the Czech Republic. 
Černý, P., (2020)

Asylum proceedings in the Czech Republic during the migration crisis

\section{Discontinue of proceedings of asylum seekers in transit}

Although the Czech Republic is not a target country for asylum seekers, but a transit country which the mainstream of asylum seekers have avoided, there was a fear of a heavy burden that could lead to the collapse of a system, as was the case in some EU border states (Greece, Italy, Hungary). For this reason, an amendment to the Act on Asylum [10], effective from 15 August 2017, was adopted. It allowed discontinuing court proceedings on review of the asylum seeker's detention if police have already released him/her from the detention. Usually, the asylum seeker immediately leaves the territory of the Czech Republic after his release and continues in his journey to the destination country. Prior to the amendment to the Asylum Act [11], administrative courts reviewed decisions on the detention of foreign citizens regardless of whether the detention had been terminated and the foreign citizen was released from the facility. According to settled case-law, the factual termination of the detention had no effect on the ability of the claim or cassation complaint to be tried by the court, and the proceedings were thus conducted even though the applicant was no longer on the territory of the Czech Republic [12].

The first to oppose this amendment was Supreme Administrative Court [13] which concluded that the application of new wording of the Asylum Act is not possible as it is contrary to European Union law, the Charter of Fundamental Rights of the European Union and the European Convention for the Protection of Human Rights (hereinafter referred to as 'the Conventio'). The Supreme Administrative Court considered this contradiction to be acte clair. The Supreme Administrative Court has seen a particular contradiction with European law with the provisions contained in Article 15 of the Procedural Directive and Articles 6 and 47 of the Charter of Fundamental Rights of the European Union in conjunction with Article 5 (4) and (5) of the Convention. According to the Supreme Administrative Court, the above-mentioned regulations do not imply any restrictions on the right to judicial review only for the period for which a foreign citizen is detained. Termination of the detention does not exclude the unlawfulness of the decision on detention. Furthermore, the Supreme Administrative Court stated that this new legislation makes it unreasonably more difficult or makes it even impossible to claim damages for unlawful detention, which is contrary to the principle of effectiveness or with the second subparagraph of Article 19 (1) of the EU Treaty. The new legislation violates EU law precisely by forcing administrative courts to discontinue judicial proceedings without carrying out a judicial review of the detention of foreigners on its merits. However, a foreign citizen urgently needs substantive judicial review so he/she could possibly claim damages or compensation for non-material harm caused by unlawful detention against the state.

This provision of the Asylum Act was then repealed by the Constitutional Court's ruling [14]. The Constitutional Court identified with the Supreme Administrative Court and stated that: 'The legitimate aims of the contested legislation are effective to control migration and undoubtedly the compliance with the legislation of the Czech Republic. These aims are realized by procedural means (the institute of discontinuance of proceedings), by which public interest receives priority and individual interest is ignored.' 
Černý, P., (2020)

Asylum proceedings in the Czech Republic during the migration crisis

\section{Transfer of the asylum seeker to the member state}

Another problem that emerged in the context of the migration crisis was the transfer of foreign citizens detained in the Czech Republic to the Member States responsible for processing their asylum applications. European Union law is based on the designation of a single state that is responsible for the examination of an asylum application, i. e. one chance only principle. Due to the overloading of some of the border Member States which were competent to deal with the application under the Dublin III Regulation, which was beyond their means, Article 3 (2) of the Dublin III Regulation [15], which had not been used so far was activated. This Article undertakes the transmitting state (in this case the Czech Republic) not to transfer the asylum seeker to the State responsible for processing the application if there are systemic flaws in the asylum procedure in that country. The obligation of border states to process asylum applications is a weakness of the whole Dublin system, as in case of strong migratory in Schengen area problems may arise in the asylum systems of a number of Member States, as happened in Hungary [16], Italy [17] and Greece. This is one of the reasons why further reform of the CEAS is being prepared.

Article 3 (2) of the Dublin III Regulation has its roots in Article 3 of the Convention, according to which a country sending a person to another state is responsible for returning this person to a place where he/she cannot be returned, even if it is indirectly through another state [18].

The courts and administrative authorities of the Czech Republic first disregarded the obligations under Article 3 (2) of the Dublin III Regulation. Most often it was the return of asylum seekers to Hungary, from where foreign citizens went through the Czech Republic most often to Germany. Thus, the real unsatisfactory situation of the asylum procedure in Hungary has not been a matter of interest in deciding on the detention of asylum seekers for long. It was argued that Hungary is an EU Member State bound by common legal rules and values and is also a signatory to the Convention and therefore provides sufficient guarantees of a fair asylum procedure. A breakthrough in the Czech Republic was brought by the judgments of the Regional Court in Prague [19], which stated that Eurostat data, as well as data submitted by the asylum seeker (appellant), showed that concerns about the failure to execute his application for international protection in Hungary within a reasonable time or even its factual failure to act, and the subsequent impossibility of effective defense against such a decision, are justified. According to the court, this represented systemic flaws that put the appellant at risk of chain refoulement, and the detention decision was therefore annulled. Subsequently, the Supreme Administrative Court of the Czech Republic, after some case-law development, concluded that 'if the administrative authority decides to detain a foreign citizen for the purpose of extradition to another Member State, it is obliged despite a relatively short period of time (hours from the initial restriction of liberty) with a view to fulfilling the purpose of detention and the possible duration of the restriction of personal freedom to deal ex officio with the question of the factual and legal feasibility of such transfer, i. e. question of possible deficiencies of the asylum procedure in the state where the foreign citizen is to be transferred [20].'

The view that the automatic transfer of an asylum seeker to the Member State concerned cannot be accepted without assessing the level of asylum proceedings in that State has recently been confirmed also by the judgment of the EU Court of Justice of 19 March 2019 
Černý, P., (2020)

in Abubacarr Jawo v the Federal Republic of Germany, case no C 163/17, in which the Court of Justice of the EU stated that it cannot be ruled out that the Common European Asylum System encounters serious functional problems in specific Member State in practice, and there is, therefore, a risk that applicants for international protection shall be subject to treatment incompatible with their fundamental rights in case of his/her transfer to this member state.

\section{The problem of transposition of procedures directive}

Another serious problem that has arisen was the full implementation of the Procedures Directive, which contains criteria that any asylum procedure in the Member States should meet. The deadline for transposition of this directive expired in July 2015 but has not yet been fully implemented by the Czech Republic. Among other changes in the asylum procedure, the Procedures Directive has brought also changes in the scope of judicial review by requiring a 'full and ex-nunc' assessment of both the factual and legal aspects of the asylum decision.

The administrative justice in the Czech Republic is based on an incomplete review of decisions of administrative authorities. In case of an asylum application, the asylum procedure is conducted by the Ministry of the Interior; an appeal against a decision not to grant asylum can be filed to the administrative court competent according to the place of residence of the asylum seeker. The Administrative Court will examine the appellant's objections to the decision and either dismiss the action as unfounded or refer the case back to the Ministry of the Interior with instructions on how to proceed. Pursuant to Section 75 (1) of Act No. 150/2002 Coll., The Code of Administrative Justice, for the administrative justice applies that the court's decision is based on the factual and legal situation of the case that existed at the time of the administrative authority's decision-making. This concept consists in that the court assesses whether the administrative authority has acted correctly and either confirms or recalls decision and returns the case for further proceedings. A new ground of action cannot be made after the expiry of deadline for bringing an action, and the possibility to bring new, so far unapplied, evidence is also limited.

On the other hand, the Procedures Directive provides for a court or tribunal to adjudicate on an appeal against asylum decision. Article 46 (3) of the Procedures Directive lays down the obligation 'that an effective legal remedy contains full and ex nunc assessment of both factual and legal aspects, including, where appropriate, an assessment of the need for international protection...' The question is what exactly the requirement for a 'full' assessment of both the factual and the legal aspects of the case means. Referring to the case-law of the Court of Justice, Marcelle Reneman [21] inclines towards the Court having to make a real assessment of factual and legal issues, including whether the facts found are correct, credible, consistent, whether the evidence provides sufficient information to assess the complex situation and whether conclusions can be drawn from them. It is therefore not necessary to fully replace the factual assessment of the determining administrative authority.

Even this narrower scope of review, which does not require a full replacement of the administrative authority's assessment by the court, requires the ability to work with information about countries of origin and access to information databases that administrative courts in the Czech Republic do not normally have.

48 Sciendo Journal of Legal Studies Volume 25 Issue 39/2020 ISSN 2457-9017; Online ISSN 2392-7054. Web: publicatii.uvvg.ro/index.php/jls. Pages $44-56$ 
Černý, P., (2020)

"Vasile Goldiş" Western University of Arad

Asylum proceedings in the Czech Republic during the migration crisis

There is a consensus in the Czech scholarly literature that the Procedures Directive requires only the right to an effective (one) legal remedy before a court or tribunal and leaves specific regulation to the Member States and does not force the Member States to create courts of appeal or cassation courts (second instance courts) [22].

In addition to the scope of review, the Procedures Directive has also regularized the moment at which the review is to be carried out (at the time of the court decision) and explicitly lays down the obligation to take into account facts at the moment of judicial review. Such a requirement of an ex nunc review combined with the need for an eventual assessment of the need for asylum leads to a conclusion about a shift towards a model where the court will grant the asylum directly. At the moment when a court carries out a full and ex nunc assessment of both factual and legal aspects, it adds evidence in relation to change of situation in the country of origin and is also required to assess the need for international protection, it should have the right to grant asylum directly. Returning the case to the administrative authority at the stage when the court has reviewed the matter to the necessary extent and concluded that there is a need for asylum it appears to be an unnecessary and ineffective step [23]. However, the administrative justice in the Czech Republic has not yet met these requirements.

Administrative courts soon concluded that the non-transposed Article 46 (3) of the Procedures Directive had a direct effect [24], but that national procedural rules and the professional strengthening of administrative courts were still lacking. The problem relating to the requirement of ex nunc assessment has so far been managed to overcome at least partially by the case-law, inter alia by Constitutional Court ruling file no. I. ÚS 425/16 of 12 April 2016. The Constitutional Court, with reference to the principles arising from the caselaw of the European Court of Human Rights and EU law, concluded that section 75 (1) of the Code of Administrative Procedure cannot be interpreted in such a way that new grounds can be raised in court in proceedings on international protection only if the applicant for international protection could not have introduced them in proceedings before the administrative authority without his own fault. The nature of these new facts and the situation of the applicant must always be considered. Only such an assessment will fulfill the right to an effective remedy or even the effectiveness of the right of asylum under Art. 43 of the Charter. '. The Constitutional Court thus emphasized that the rule resulting from Section 75 (1) of the Code of Administrative Procedure is not uncommon. In view of the constitutional order and the transnational legislation by which the Czech Republic is bound, its interpretation can be broadened and thus divert from the current concept of review.

The recent conclusions of the EU Court of Justice in the Alheto case [25] are also relevant to this problem. In the Alheto judgment, the Court of Justice of the EU concluded that a court of a Member State which is hearing an appeal against a decision on an application for international protection at first instance must assess not only both the factual and legal circumstances which the authority that took the decision took or could take into account but also the circumstances which have arisen after the adoption of that decision. In this judgment, the EU Court of Justice interprets the requirement for a full and ex nunc assessment in a way that the court effectively carries out the assessment even to a wider extent than the determining authority. The Court must take into account not only the circumstances which the determining authority has taken into account but also those which it could (and did not) 
Černý, P., (2020)

take into account and those which it could not take into account, since they occurred after the decision was taken. Thus, review in international protection proceedings goes beyond the principle of full jurisdiction and the court may, in fact, replace the assessment made by the determining authority.

Given that the full transposition of Article 46 (3) of the Procedures Directive would mean a significant change in the whole concept of administrative justice, the Czech legislature has not yet transposed it and does not appear to plan it.

\section{Detention of a foreign citizen due to the serious risk of absconding}

The Dublin III Regulation contains a separate regulation for detaining a foreign citizen for the purpose of transferring him/her to the Member State responsible for processing his/her asylum application (Article 28 of the Dublin III Regulation). It, therefore, leaves no room for the adoption of national rules. The reason for this legislation was that Member States' national legislation dealt with the issue of detention differently, even though they were all based on the same human rights framework of the Convention and later on also on the EU Charter [26]. This amendment of the Regulation copies the algorithm of conditions for interference with individual freedom defined by the EU Charter. It contains an explicit requirement for the proportionality of such intervention to the applicant's circumstances, meaning the protection of some particularly vulnerable groups. The Dublin III Regulation also includes a condition for the necessity of intervention, expressed through the requirement of ineffectively of soft measures (alternatives to detention). Detention under Article 28 of the Dublin III Regulation can never be an automatic step linked with the submission of an asylum application and initiation of the Dublin procedure leading to finding out the State competent to decide about the application. Detention is always a means of ultima racio to ensure the successful completion of the procedure by transferring the asylum seeker. In addition, the requirement of the necessity of detention is also hidden in the rigid regulation of the maximum allowed duration of detention, which represents only the necessary time required to carry out the procedure, further limited by a maximum period of 6 weeks from the compliance with a request for taking charge by a Member State (cf. Article 28 (3)). If there are delays in the proceedings or if the administrative authority considers that the transfer is not possible, it exceeds the time necessary to carry out the proceedings and the detention must be terminated immediately.

In the following case, we will show the problem of implementing the Dublin III Regulation not only in the Czech Republic but also in Germany and Austria. A group of Iraqi citizens was detained in the Czech Republic in August 2015 on their illegal journey to Germany. These citizens traveled from Iraq first to Turkey and then to Greece. From there they continued in the lorry. They were detained by police in Hungary. At the Hungarian police service, their fingerprints were taken into the EURODAC system and they were registered as asylum seekers. The day after they were brought to the train station with instructions to go to the refugee camp. For this purpose, the Hungarian police gave them train tickets and a map. They spent about two days in the camp, then, along with other fellow countrymen, they paid the smugglers to transport them to Germany. After their detention, Czech police found from the EURODAC database that these citizens are asylum seekers in Hungary and that they have no residence title or travel document for their stay in the Czech Republic. They did not have

50 sciendo Journal of Legal Studies Volume 25 Issue 39/2020 ISSN 2457-9017; Online ISSN 2392-7054.

Web: publicatii.uvvg.ro/index.php/jls. Pages $44-56$ 
Černý, P., (2020)

"Vasile Goldiş" Western University of Arad

Asylum proceedings in the Czech Republic during the migration crisis

the money to secure their own accommodation until the Dublin III transfer was carried out or anyone they could turn to in the Czech Republic. As it wasn't possible to use soft measures, a reason for detention under Article 28 of the Dublin III Regulation was given in order to transmit them to Hungary as a state responsible for examining and processing their asylum application. The police considered whether the condition of serious risk of absconding under Article 28 (2) of the Dublin III Regulation was also met. A condition of serious risk of absconding is necessary in order to detain a foreign citizen. These persons did not comply with the conditions laid down in the asylum application procedure in Hungary as they did not stay in the reception center until their application was decided and, moreover, they were aware that their further movement within the European Union was illegal. They indicated that they intended to continue their journey to Germany. Based on the above the police considered that there was a serious risk of absconding and therefore they were detained.

These citizens challenged the police decision on detention by bringing an action to the administrative court. The Regional Court in Ústí nad Labem annulled the decision by the judgment dated 1 June 2015, case no 42 And 12 / 2015-78. On the grounds of the judgment, the court stated that under Article 28 (2) of the Dublin III Regulation, a person can only be detained if there is a serious risk of absconding based on the assessment of each individual case. Objective criteria for assessing whether there is a serious risk of absconding from the detained person must be in accordance with Article 2(n) the Dublin III Regulation [27] regulated by law, which also results from a comparison of the different language versions of the Dublin III Regulation. However, no Czech legislation contained these criteria. Article 28 (2) of the Dublin III Regulation was therefore declared inapplicable by the Regional Court in the Czech Republic. In this judgment, the Regional Court agreed with the decision of the German Federal Administrative Court of 26 June 2014, case no V ZB 31/14, and with the decision of the Austrian Administrative Court of Justice of 19 February 2015, case no Ro 2014/21/0075-5, according to which the absence of objective criteria on the basis of which a serious risk of absconding can be assessed in any particular case, makes the detention according to Article 28 of the Dublin III Regulation inapplicable.

This was a serious problem as it concerned the detention of many foreigners who were to be transferred to another Member State for the purpose of processing their asylum application in that Member State. The Supreme Administrative Court [28] therefore referred the following question to the Court of Justice for a preliminary ruling: 'Does the very fact that the law does not define objective criteria for assessing the serious risk of a foreigner absconding [Article 2 (n) of Regulation No 604/2013 (OJ L 180, 29. 6. 2013, p. 31)], have the effect of inapplicability of the institution of detention under Article 28 (2) of that regulation?'

The EU Court of Justice decided the case by judgment of 15 March 2017 in Al Chodor and Others, case no C-528/15, stating that Article 2 (n) of the Dublin III Regulation in connection with Article 28 (2) thereof, imposes an obligation on the Member States to lay down objective criteria by generally binding legislation which constitute sufficient grounds on which can be considered that the applicant for international protection with whom the relocation procedure is held, may escape. In the absence of such legislation, Article 28 (2) of this Regulation is not applicable. 
Černý, P., (2020)

The EU Court of Justice also disagreed, inter alia, that the concept of 'legislation' in Article 2 (n) of the Dublin III Regulation could be understood as if including settled case-law, possibly confirming settled administrative practice, provided that the grounds for a serious risk of absconding are sufficiently defined by them.

According to the EU Court of Justice, detention of a foreign citizen is a restriction on the exercise of the fundamental right to freedom embedded in Article 6 of the EU Charter of Fundamental Rights. It follows from Article 52 (1) of the EU Charter that any restriction on the exercise of this right must be determined by the law and must respect the substance of that right and the principle of proportionality. At the same time, considering Article 52 (3) of the EU Charter, Article 5 of the Convention should be considered as a minimum level of protection for the purpose of interpreting Article 6 of the EU Charter. According to the European Court of Human Rights, all deprivation of liberty must not only be legal in the sense that it must have a legal basis in national law, but it also affects the qualitative aspect of the law and implies that national law allowing deprivation of liberty must be sufficiently accessible, accurate and predictable to avoid any risk of arbitrariness [29].

Therefore, according to the EU Court of Justice, detention is subject to strict safeguards such as the existence of a legal basis, clarity, predictability, availability, and protection against arbitrariness. In view of the purpose of the provisions in question and the high level of protection that follows from their context, only generally binding legislation can satisfy the requirements of clarity, predictability, accessibility, and protection against arbitrariness. In conclusion, the Court of Justice also pointed out that the non-definition of objective criteria by a generally binding provision leads to the unlawfulness of detention and inapplicability of Article 28 (2) of the Dublin III Regulation.

Until 17 December 2015 Czech legal order did not contain any definition of objective criteria for assessing the existence of a risk absconding. Such criteria were added to the Act No. 326/1999 Coll., On the Residence of Foreign Nationals, under which detention was also carried out, with the effect from 18 December 2015 [30]. The aforementioned lack of legal order had real impacts in the Czech Republic as it led to the various release of foreigners from detention or the impossibility of their detention.

\section{Conclusions}

The most serious problem in meeting the requirements of EU law has been full and ex nunc review of decisions on asylum applications, which do not fit into the concept of the Czech administrative justice and causes a number of practical problems, as the legislation is not adapted to these requirements at all. In contrast to the review of other administrative decisions, it imposes on the courts the requirement to decide not only on the basis of the legal and factual situation at the date of the decision but also on the basis of the legal and factual situation at the date of the court decision. It is necessary for the Czech legislator to fulfill its obligation under EU law and transpose Article 46 (3) of the Procedures Directive into the Czech legal order, but this is not likely to take place in view of the anticipated high financial costs. The current state of uncertainty where it is not clear which provisions of the Code of Administrative Procedure are not applied as a result of this article is undesirable. Transposition cannot be replaced by the decision-making practice of the courts which is moreover inconsistent (e.g. on the question which new facts can be claimed by the applicant

52 sciendo Journal of Legal Studies Volume 25 Issue 39/2020 ISSN 2457-9017; Online ISSN 2392-7054. Web: publicatii.uvvg.ro/index.php/jls. Pages $44-56$ 
Černý, P., (2020)

Asylum proceedings in the Czech Republic during the migration crisis

in front of the court). Along with the insufficient provision of conditions that would enable administrative courts to fulfill their obligations in asylum proceedings, the legislature's lax approach could result in the situation when the right to an effective legal remedy before a court under Article 46 of the Procedures Directive is not effectively guaranteed.

Another serious problem which, however, has already been resolved was the absence of the definition of objective criteria in the law according to which the risk of escape and the resulting ability to secure a foreigner would be assessed. Apart from the Czech Republic, this problem has occurred at least in Germany and Austria. It can be considered that this could be due to several factors. Firstly, this may be because the obligation to adopt specific legislation of a particular content is typical for directives, while regulations are directly applicable in the Member States and thus complexity is assumed so it can be applied. The second reason may be that the obligation to adopt legislation or to add legislation concerning the detention, was included in one of the introductory articles of the Dublin III Regulation, known as 'Definitions'. For these reasons, this obligation was apparently overlooked. This case also has a wider impact in the sense that it has been confirmed by the EU Court of Justice that a law cannot be replaced by administrative or judicial practice and therefore if legislation speaks about law, it must be from the formal and content side the law which means an act issued by the legislative power. Thus, the law as a manifestation of the activity of the legislative power cannot be replaced by the activity of another power of the state, and thus neither by the activity of the judicial or executive power.

\section{Acknowledgments}

The author thanks the anonymous reviewers and editor for their valuable contribution.

\section{Funding}

This research received no specific grant from any funding agency in the public, commercial, or not - for - profit sectors.

\section{Author Contributions}

The entire article was written by Petr Černý.

\section{Disclosure Statement}

The author has not any competing financial, professional, or personal interests from other parties.

\section{References}

1. ECRE. Asylum Information Database. (2017). Country report: Italy. https://www.asylumineurope.org/sites/default/files/report-

download/aida_it_2017update.pdf.

2. Filipová, J. (2008). Tzv. nepřijatelnost kasační stížnosti o mezinárodní ochraně podle § 104a s.ř.s. In Dny práva - 2008 - Days of Law. Brno: Tribun EU, s.r.o., s. 1394, https://www.law.muni.cz/sborniky/dp08/files/pdf/sprava/filipova.pdf. 
Černý, P., (2020)

Asylum proceedings in the Czech Republic during the migration crisis

3. Hailbronner, K., Thym, D. (Eds.), (2016). EU Immigration and Asylum Law. 2. vyd. München: C. H. Beck.

4. Hathaway, J.C. (2005). The rights of refugees under international law. Cambridge: Cambridge University Press, doi:10.1017/CBO9780511614859.

5. Holoubková, H. (2018). Úplné a ex nunc posouzení jak skutkové, tak právní stránky v řízení o žalobě proti rozhodnutí ve věci mezinárodní ochrany v procesním prostředí českého soudního řádu správního. In Ročenka uprchlického a azylového práva. Brno: Veřejný ochránce práv.

6. Jurníková, J., Králová, A. (2016). Komu svěřit posuzování a přezkum žádostí o mezinárodní ochranu? Časopis pro právní vědu a praxi, č. 2, s. 131.

7. Králová, A. (2018). Vliv unijního práva na systém opravných prostředků v cizineckém právu. In Ročenka uprchlického a azylového práva. Brno: Veřejný ochránce práv.

8. Loprieno, D. (2019). The Italian Decree on Immigration: Where next?, http://www.glimer.eu/italian-decree-on-immigration/.

9. Müller, D. (2019). Nový italský azylový zákon - první vlaštovka restriktivního př́istupu členských států Evropské unie k žadatelům o mezinárodní ochranu?. Správní právo, č. 5, s. 300.

10. Reneman, M. (2014). EU asylum procedures and the right to an effective remedy. Oxford: Hart publishing.

11. Scheu, H.S. (2016). Listina základních práv EU jako referenční rámec národního azylového práva. AUC-Iuridica, č. 2, s. 17.

12. Tineke, S. (2008). Procedures Directive: An Overview. In Zwan Karin (ed.). The Procedures Directive: Central Themes, Problem Issues, and Implementation in Selected Member States. Nijmegen: Wolf Legal Publishers.

13. UNHCR. (2010). Improving Asylum Procedures. Comparative Analysis and Recommendations for Law and Practise. Key Findings and Recomendations (online), https://www.unhcr.org/4ba9d99d9.html.

14. Zimmermann, A., Dörschner, J., Machts, F. (2011). The 1951 Convention relating to the Status of Refugeesand its 1967 Protocol. Commentary. Oxford: University Press.

\section{Notes}

[1] Zimmermann, A., Dörschner, J., Machts, F., 2011, p. 1936.

[2] In more detail Hathaway, J.C., 2005, p. 279.

[3] Directive 2011/95/EU of the European Parliament and of the Council of 13 December 2011 on standards for the qualification of third-country nationals or stateless persons as beneficiaries of international protection, for a uniform status for refugees or for persons eligible for subsidiary protection, and for the content of the protection granted.

[4] Directive 2013/32/EU of the European Parliament and of the Council of 26 June 2013 on common procedures for granting and withdrawing international protection.

[5] Directive 2013/33/EU of the European Parliament and of the Council of 26 June 2013 laying down standards for the reception of applicants for international protection.

[6] Regulation (EU) No 604/2013 of the European Parliament and of the Council of 26 June 2013 establishing the criteria and mechanisms for determining the Member State responsible for examining an application for international protection lodged in one of the Member States

54 sciendo Journal of Legal Studies Volume 25 Issue 39/2020 ISSN 2457-9017; Online ISSN 2392-7054 
Černý, P., (2020)

Asylum proceedings in the Czech Republic during the migration crisis

by a third-country national or a stateless person. Part of CEAS is also Council Regulation (EC) No 2725/2000 of 11 December 2000 concerning the establishment of 'Eurodac' for the comparison of fingerprints for the effective application of the Dublin Convention or Regulation (EU) No 1052/2013 of the European Parliament and of the Council of 22 October 2013 establishing the European Border Surveillance System (Eurosur). Also Council Directive 2001/55/EC of 20 July 2001 on minimum standards for giving temporary protection in the event of a mass influx of displaced persons and on measures promoting a balance of efforts between the Member States in receiving such persons and bearing the consequences thereof.

[7] Article 8 of the preamble of qualification directive.

[8] UNHCR. 2010; Tineke S. 2008, p. 19.

[9] In more detail Loprieno, D. (2019), Müller, D. (2019).

[10] Section 46a (9) of the Act no 325/1999 Coll., On Asylum, effective until 21 January 2019, when it was annulled by the Constitutional Court of the Czech Republic, by the amendment no 222/2017 Coll.

[11] Equally amended Section 172 (6) of the Act No. 326/1999 Coll., On the Residence of Foreign Nationals on the territory of the Czech Republic, which also made discontinuance of proceedings after his/her release from detention possible.

[12] Cf. e.g. Decisions of the Supreme Administrative Court dated 31 October 2016, case no 8 Azs 58/2016-36; dated 13 December 2005, case no 4 Azs 128/2005-5; dated 21 July 2005, case no 7 Azs 101/2005-46, www.nssoud.cz.

[13] Decision of the Supreme Administrative Court dated 29 November 2017, case no 6 Azs 320/2017-20, available at www.nssoud.cz.

[14] Ruling of the Constitutional Court of the Czech Republic dated 27 November 2018, case no Pl. ÚS 41/17.

[15] „Where it is impossible to transfer an applicant to the Member State primarily designated as responsible because there are substantial grounds for believing that there are systemic flaws in the asylum procedure and in the reception conditions for applicants in that Member State, resulting in a risk of inhuman or degrading treatment within the meaning of Article 4 of the Charter of Fundamental Rights of the European Union, the determining Member State shall continue to examine the criteria set out in Chapter III in order to establish whether another Member State can be designated as responsible.“

[16] Existence of systemic flaws in Hungary was declared as a notorious fact by Supreme Administrative Court in the decision dated 12 September 2016, case no 5 Azs 195/2016-22, available at www.nssoud.cz.

[17] ECRE (2017).

[18] Cf. judgment of the European Court of Human Rights dated 23 February 2012, Hirsi Jamaa and others v. Italy, application no 27765/09.

[19] Decisions of the Regional Court in Prague dated 14 January 2016, case no $49 \mathrm{Az}$ 97/2015-82, case no $49 \mathrm{Az}$ 109/2015-74 and case no 49 Az 110/2015-79.

[20] Subsection 20 of the decision of the Supreme Administrative Court dated 17 April 2018, case no 4 Azs 73/2017-29.

[21] Reneman. 2014, s. $282-283$.

[22] Filipová. 2008, Scheu. 2016. 
Černý, P., (2020)

Asylum proceedings in the Czech Republic during the migration crisis

[23] Jurníková, J., Králová, A. (2016), s. 137.

[24] As the first probably the decision of the Regional Court in Prague dated 24 August 2015, case no 45 Az 30/2014-57.

[25] Judgment of the EU Court of Justice dated 25 July 2018, case no C-585/16.

[26] Hailbronner, K., Thym, D. (2016), p. 1574.

[27] Article 2(n) of the Dublin III Regulation states, that „risk of absconding' means the existence of reasons in an individual case, which are based on objective criteria defined by law, to believe that an applicant or a third-country national or a stateless person who is subject to a transfer procedure may abscond.

[28] Resolution of Supreme Administrative Court dated 24 September 2019, case no 10 Azs 122/2015-88, www.nssoud.cz.

[29] Cf. the judgment of the European Court of Human Rights dated 21 October 2013, Del Río Prada v. Spain, application no. 42750/09, article 125.

[30] Pursuant to Section 129 (4) of the Act No. 326/1999 Coll., On the Residence of Foreign Nationals on the territory of the Czech Republic, in the wording effective as of 18 December 2015, the following applies: "For a serious risk of absconding is considered if the foreign citizen stayed illegally on the territory, if he/she avoided transfer to a state bound by a directly applicable regulation of the European Union, or tried to escape or has expressed an intention not to respect a legally effective decision on transfer to a state bound by a directly applicable regulation of the European Union, or if such an intention is apparent from his behavior. For a serious risk of absconding is considered also if the foreign citizen will be transferred to the state bound by a directly applicable regulation of the European Union which is not neighboring Czech Republic, and who cannot travel to this state on his own and cannot state the address of his place of residence on the territory." 